\title{
The Interaction of Vasoactive Intestinal Polypeptide (VIP), Glucose and Arginine on the Secretion of Insulin, Glucagon and Somatostatin in the Perfused Rat Pancreas
}

\author{
J. Szecówka, E. Sandberg, and S. Efendić \\ Department of Endocrinology, Karolinska Hospital, Stockholm, Sweden
}

Summary. Vasoactive Intestinal Polypeptide (VIP) increased the release of insulin, glucagon and somatostatin from the perfused rat pancreas. The amount of these hormones released was dependent upon the prevailing glucose concentration. VIP stimulated glucagon release in the absence of glucose, while insulin and somatostatin release were increased by VIP only in the presence of glucose concentrations of $4.4 \mathrm{mmol} / 1$ and above. Glucagon secretion stimulated by arginine in the presence of $4.4 \mathrm{mmol} / 1$ glucose was potentiated by VIP. In contrast, VIP did not induce any further increase in the secretion of insulin and somatostatin over that stimulated by arginine. At higher concentrations of glucose $(6.7,16.7$, and $33.3 \mathrm{mmol} / \mathrm{l}) \mathrm{VIP}$ continued to stimulate insulin and somatostatin release, this effect being synergistic on early-phase insulin release. The effects of VIP on islet cells thus depend on the levels of modulating nutrients.

Key words: VIP, insulin, glucagon, somatostatin, glucose, arginine, perfused rat pancreas.

Vasoactive Intestinal Polypeptide (VIP) was first isolated from porcine duodenum [22]. Using antibodies against pure porcine VIP in immunoperoxidase and immunofluorescence tests, VIP-immunoreactive cells have been detected in the islets in dog, guinea-pig, and man, but not in rats ([2]; Schultzberg and Hökfelt, personal communication). VIP has also been found in the central nervous system [13, 14] and in peripheral nerves $[15,19,27,28]$. In the pancreas, VIP containing nerves have been seen in connective tissues within the exocrine pancreatic parenchyma, and also in association with islets [27].

VIP stimulates insulin and glucagon release from isolated perfused porcine pancreas [16] as well as from dog pancreas perfused in situ [12] which, together with the occurrence of VIP in islets, suggests that the peptide may be of importance for the regulation of the secretion of islet hormones.

The present study was designed to characterize the effects of VIP on the release of insulin, glucagon, and somatostatin from the isolated perfused rat pancreas. The study was further extended to investigate the interaction of VIP, glucose, and arginine on pancreatic hormone release.

\section{Material and Methods}

Sprague-Dawley rats (Anticimex, Stockholm), weighing 200$250 \mathrm{~g}$, and fed ad libitum, were anaesthetized by IP injection of $50 \mathrm{mg} / \mathrm{kg}$ of pentobarbitone and the pancreas isolated [17]. The perfusing medium, a red-cell free Krebs-Ringer bicarbonate solution containing $2 \mathrm{~g} / 100 \mathrm{ml}$ bovine serum albumin, was infused into the coeliac artery, and run into the prepared pancreas by an open circuit, a "non-recycling perfusion system" [17]. The rate of perfusion was approximately $3.0 \mathrm{ml} / \mathrm{min}$. The pancreas was equilibrated by perfusion for 20 min before the start of the experiments.

Insulin was measured by radioimmunoassay using a rat insulin standard [10]. The sensitivity of the assay was about $300 \mathrm{ng} / \mathrm{l}$ and the coefficient of variation $\pm 10 \%$. Glucagon was assayed by the charcoal separation technique with an antibody specific for pancreatic glucagon " $30 \mathrm{~K}$ " [8]. The sensitivity of this assay was about $50 \mathrm{ng} / 1$ and the coefficient of variation $\pm 7 \%$. Somatostatin was measured by a radioimmunoassay using locally produced antibodies [4]. Cross-reactivity of this antibody was less than $0.01 \%$ with insulin, glucagon, VIP, substance P, LH-RH, vasopressin, and oxitocin. The sensitivity of the somatostatin assay was about $5 \mathrm{ng} / \mathrm{l}$ and coefficient of variation $\pm 15 \%$.

Pure, natural, porcine VIP was kindly provided by Professor V. Mutt, Karolinska Institute, Stockholm.

The amounts of insulin and somatostatin released were determined by integrating the areas under the respective curves. The initial phase of insulin and somatostatin release corresponds to 

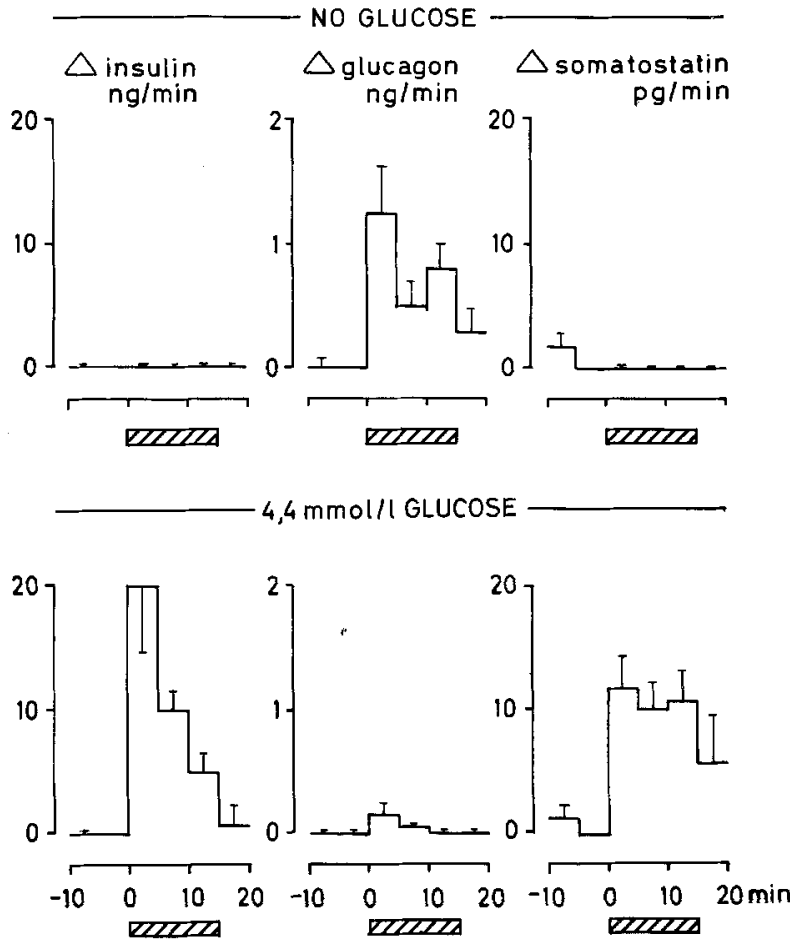

VIP Eerea $1 \mathrm{nmol} / 1$

Fig 1. Effect of a 15 -min infusion of VIP (1 nmol/l) on insulin, glucagon and somatostatin release from the isolated perfused rat pancreas in the absence (upper panel) and presence (lower panel) of $4.4 \mathrm{mmol} / \mathrm{l}$ glucose. Results are expressed as mean $\pm \mathrm{SEM}(\mathrm{n}=$ 6). Basal hormone release rates were: At $0 \mathrm{mmol} / 1$ glucose: insulin: $0 \mathrm{ng} / \mathrm{min}$ - glucagon: $3.04 \pm 0.10 \mathrm{ng} / \mathrm{min}$ - somatostatin: $2.8 \pm$ $1.0 \mathrm{pg} / \mathrm{min}$. At $4.4 \mathrm{mmol} / \mathrm{l}$ glucose: insulin: $2.20 \pm 0.26 \mathrm{ng} / \mathrm{min}-$ glucagon: $0.37 \pm 0.05 \mathrm{ng} / \mathrm{min}$ - somatostatin: $12.3 \pm 1.6 \mathrm{pg} / \mathrm{min}$

$\triangle$ insulin $\mathrm{ng} / \mathrm{min}$
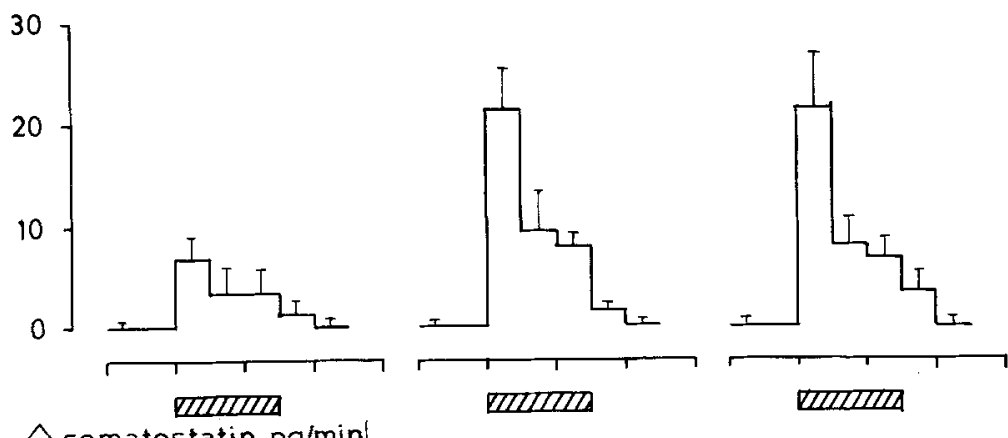

$\triangle$ somatostatin $\mathrm{pg} / \mathrm{min}$

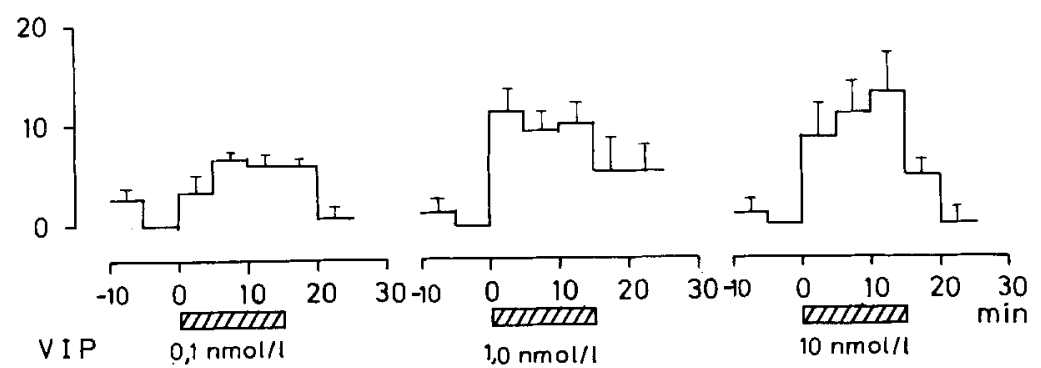

Fig 2. Effect of a 15-min infusion of VIP $(0.1,1.0$, $10.0 \mathrm{nmol} / \mathrm{l})$ on insulin and somatostatin release from the isolated perfused rat pancreas. The perfusing medium contained $4.4 \mathrm{mmol} / 1$ glucose. Results are given as mean $\pm \operatorname{SEM}(n=6)$. Basal hormone release rates were: insulin: $2.20 \pm 0.26 \mathrm{ng} / \mathrm{min}-$ somatostatin: $12.3 \pm 1.6 \mathrm{pg} / \mathrm{min}$
0-7 min after the start of the stimulation, while the second phase comprises the period between 7 and $60 \mathrm{~min}$. Conventional statistical methods were employed. The results are expressed as mean \pm

\section{Results}

Glucose Dependence of the Effect of VIP on the Release of Insulin, Glucagon and Somatostatin (Fig. 1)

In the absence of glucose in the perfusing medium, VIP ( $1 \mathrm{nmol} / \mathrm{l})$ markedly enhanced glucagon release. The effect was most pronounced during the first five minutes of VIP administration. The peptide alone had no effect on insulin and somatostatin secretion. In contrast, in the presence of $4.4 \mathrm{mmol} / 1$ glucose in the perfusing medium, VIP stimulated the release of insulin and somatostatin but not of glucagon (Fig. 1).

\section{Dose Dependence of the Insulin and Somatostatin Response to VIP (Fig. 2)}

In these experiments, the pancreas was perfused with a medium containing $4.4 \mathrm{mmol} / \mathrm{l}$ glucose. The lowest dose of VIP used $(0.1 \mathrm{nmol} / \mathrm{l})$ significantly enhanced insulin as well as somatostatin release. The release of these hormones was maximally stimulated by the presence of $1 \mathrm{nmol} / 1 \mathrm{VIP}$. Irrespective of the dose of VIP, insulin response was stimulated most during the first five minutes of the administration of the peptide, while somatostatin response to VIP persisted at the same level during the entire experiment (Fig. 2). 


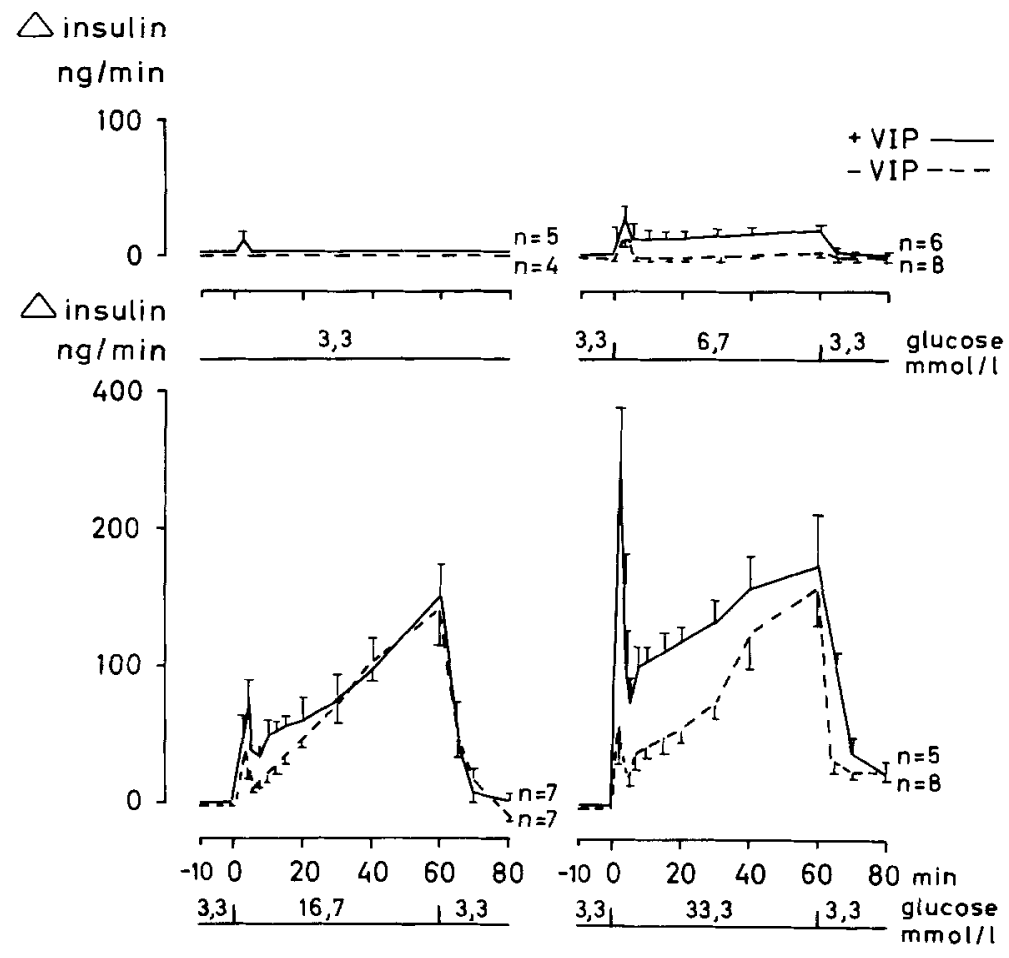

Fig 3. Effect of VIP $(1 \mathrm{nmol} / 1)$ on insulin release stimulated by increasing concentrations of glucose. The isolated perfused rat pancreas was equilibrated for $20 \mathrm{~min}$ with $3.3 \mathrm{mmol} / \mathrm{l}$ glucose prior to stimulation with higher glucose doses (0-60 min). Broken lines indicate control experiments and solid lines experiments with VIP. VIP was infused from $0-60 \mathrm{~min}$. Results are given as mean $\pm \mathrm{SEM}$. Basal insulin release: $1.70 \pm 0.22 \mathrm{ng} / \mathrm{min}$

Table 1. Effect of VIP $(1 \mathrm{nmol} / \mathrm{l})$ on glucose induced insulin response of the isolated rat pancreas. Insulin release was calculated by determining incremental area over basal values. NS = not significant

\begin{tabular}{|c|c|c|c|c|c|c|}
\hline \multirow{3}{*}{$\begin{array}{l}\text { Glucose } \\
\text { concentration } \\
\mathrm{mmol} / \mathrm{l}\end{array}$} & \multicolumn{6}{|c|}{ Insulin release $\left(\mathrm{ng} \times \min \times \mathrm{ml}^{-1}\right)$} \\
\hline & \multicolumn{3}{|l|}{$\underline{1-7 \mathrm{~min}}$} & \multicolumn{3}{|l|}{$7-60 \mathrm{~min}$} \\
\hline & glucose & $\begin{array}{l}\text { glucose } \\
+ \text { VIP }\end{array}$ & $\mathrm{P}$ & glucose & $\begin{array}{l}\text { glucose } \\
+ \text { VIP }\end{array}$ & $\mathrm{P}$ \\
\hline 3.3 & 0 & $12 \pm 3$ & $<0.0025$ & 0 & 0 & 0 \\
\hline 6.7 & $33 \pm 2$ & $76 \pm 4$ & $<0.0025$ & $140 \pm 27$ & $240 \pm \quad 21$ & $<0.0025$ \\
\hline 16.7 & $155 \pm 21$ & $268 \pm 32$ & $<0.0025$ & $3893 \pm 332$ & $4166 \pm 707$ & NS \\
\hline 33.3 & $225 \pm 23$ & $666 \pm 99$ & $<0.0025$ & $5468 \pm 573$ & $6230 \pm 1000$ & NS \\
\hline
\end{tabular}

Interaction of Glucose and VIP on the Release of Insulin and Somatostatin (Figs. 3 and 4)

In these experiments, the pancreas was first equilibrated for $20 \mathrm{~min}$ with a perfusion medium containing $3.3 \mathrm{mmol} / 1$ glucose. In the control experiments, the pancreas was then stimulated by increasing glucose concentrations $(6.7,16.7$, and $33.3 \mathrm{mmol} / \mathrm{l})$. In the experiments with VIP, glucose and $1 \mathrm{nmol} / \mathrm{l}$ of VIP were perfused simultaneously. As expected, administration of glucose induced a biphasic insulin response. Significant stimulation of insulin release was seen when the glucose concentration was increased from $3.3 \mathrm{mmol} / \mathrm{l}$ to $6.7 \mathrm{mmol} / \mathrm{l}$.

Analysis of the two series of results (Fig. 3, Table 1) shows that at all glucose concentrations used, VIP and glucose exerted synergistic effects on the early phase of insulin release. Late insulin release was significantly enhanced by VIP only in the presence of $6.7 \mathrm{mmol} / 1$ glucose. VIP significantly enhanced both the early and the late phase of somatostatin release in the presence of $6.7 \mathrm{mmol} / 1$ glucose $(P<0.01)$ and the early phase with $16.7 \mathrm{mmol} / \mathrm{l}$ of the hexose (Fig. 4 , Table 2).

\section{Effect of VIP on Arginine Induced Release of Insulin, Glucagon and Somatostatin (Fig. 5)}

Arginine $(20 \mathrm{mmol} / \mathrm{l})$ significantly stimulated the release of insulin, glucagon, and somatostatin from. pancreas perfused with a medium containing $4.4 \mathrm{mmol} / \mathrm{l}$ glucose. The effect was most pronounced 
$\triangle$ somatostatin $\mathrm{pg} / \mathrm{min}$

$+V \operatorname{IP}-$
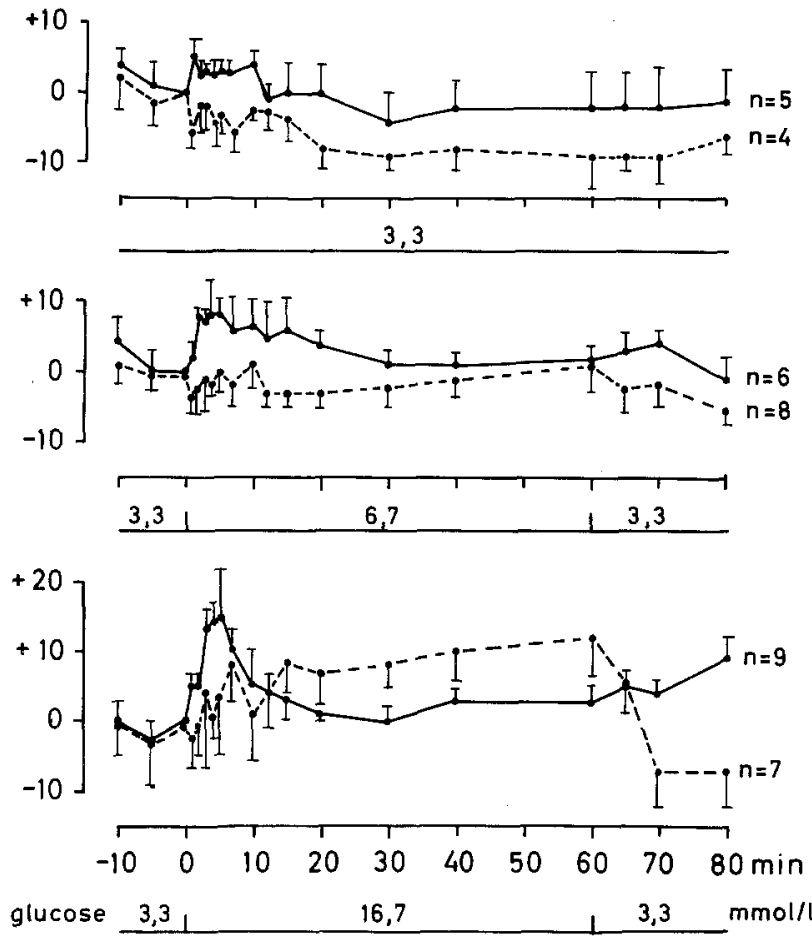

Fig 4. Effect of VIP (1 nmol/1) on somatostatin release at increasing concentrations of glucose. The isolated perfused rat pancreas was equilibrated for $20 \mathrm{~min}$ with $3.3 \mathrm{mmol} / 1$ glucose prior to application of higher glucose concentration $(0-60 \mathrm{~min})$. Broken lines denote control experiments and solid lines experiments with VIP. VIP was infused from $0-60 \mathrm{~min}$. Results are given as mean \pm SEM. Basal somatostatin release: $4.3 \pm 1.2 \mathrm{pg} / \mathrm{min}$ during the first $5 \mathrm{~min}$. VIP significantly enhanced arginine induced glucagon release, whereas there was no such effect on insulin and somatostatin secretion (Fig. 5).

\section{Discussion}

VIP containing nerves occur in rat islets ([27]; Schultzberg and Hökfelt, personal communication). The present study demonstrates that in rat VIP stimulates the release of insulin, glucagon and somatostatin from the isolated perfused pancreas, depending on glucose concentration. VIP had a similar effect in the perfused pancreas of other species, in that it stimulated insulin and glucagon release from the porcine pancreas, and insulin and somatostatin from the canine pancreas $[12,16]$.

In our experimental system VIP stimulated glucagon release in the absence of glucose. In contrast, at $4.4 \mathrm{mmol} / 1$ glucose level, the peptide significantly enhanced the secretion of insulin and somatostatin but not of glucagon. Dependence of the effect of VIP on glucose concentration in the perfusing medium also occurs in the isolated porcine pancreas [16]. However, in the porcine pancreas, VIP stimulated glucagon release even in the presence of $5.0 \mathrm{mmol} / 1$ glucose, and it was only when the glucose concentration was increased to a hyperglycaemic level $(7.5 \mathrm{mmol} / \mathrm{l})$ that VIP enhanced insulin release. Furthermore, under normoglycaemic conditions in the in situ perfused cat pancreas VIP was more

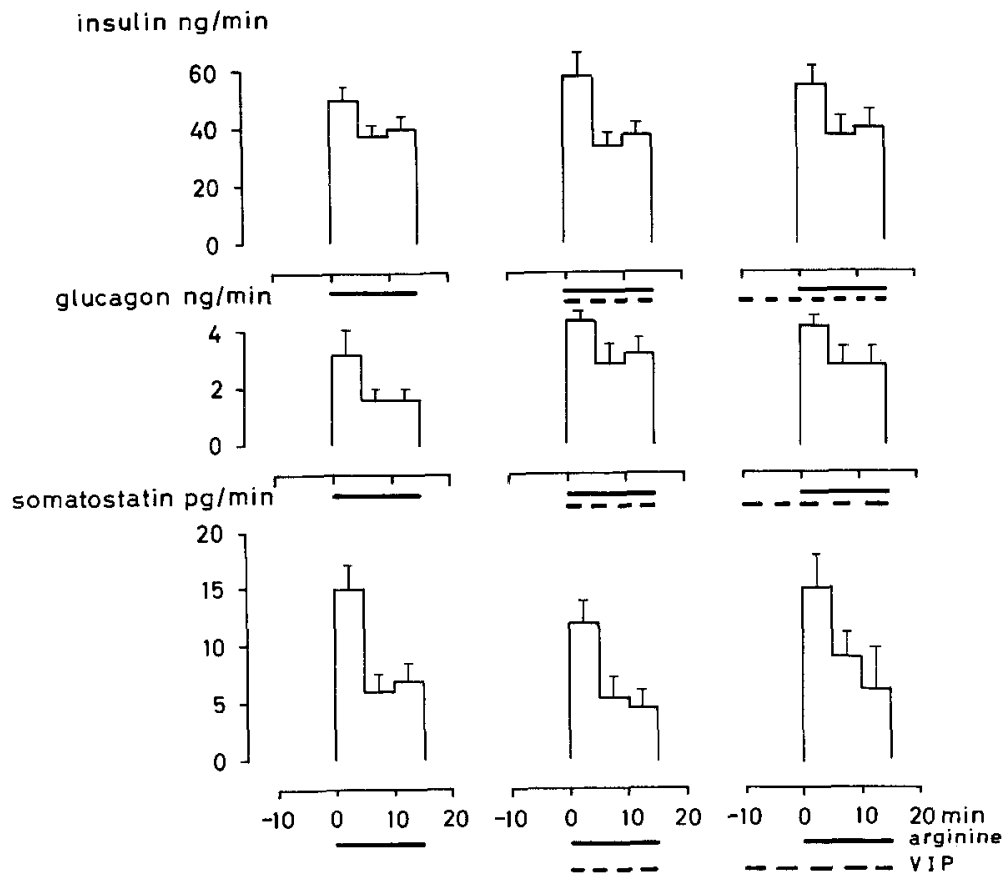

Fig 5. Effect of VIP ( $1 \mathrm{nmol} / \mathrm{l})$ on arginine $(20 \mathrm{mmol} / \mathrm{l})$ induced insulin, glucagon, and somatostatin release from the isolated perfused rat pancreas. Glucose concentration in the perfusate was $4.4 \mathrm{mmol} / \mathrm{l}$. Columns represent insulin, glucagon, somatostatin output during $5 \mathrm{~min}$. Results are given as mean $\pm \operatorname{SEM}(\mathrm{n}=6)$. Basal hormone release rates were: insulin: $2.70 \pm 0.34 \mathrm{ng} / \mathrm{min}-$ glucagon: $0.43 \pm 0.02 \mathrm{ng} / \mathrm{min}$ - somatostatin: 17.2 $\pm 7.8 \mathrm{pg} / \mathrm{min}$ 
Table 2. Effect of VIP $(1 \mathrm{nmol} / \mathrm{l})$ on glucose induced somatostatin release from the isolated perfused rat pancreas. Somatostatin release was calculated by determining incremental area over basal levels. NS = not significant

\begin{tabular}{|c|c|c|c|c|c|c|}
\hline \multirow{3}{*}{$\begin{array}{l}\text { Glucose } \\
\text { concentration } \\
\text { mmol/ } /\end{array}$} & \multicolumn{6}{|c|}{ Somatostatin release $\left(\mathrm{pg} \times \min \times \mathrm{ml}^{-1}\right)$} \\
\hline & \multicolumn{3}{|l|}{$1-7 \mathrm{~min}$} & \multicolumn{3}{|l|}{$7-60 \mathrm{~min}$} \\
\hline & glucose & $\begin{array}{l}\text { glucose } \\
+ \text { VIP }\end{array}$ & $\bar{P}$ & glucose & $\begin{array}{l}\text { glucose } \\
+ \text { VIP }\end{array}$ & $\mathrm{P}$ \\
\hline 3.3 & $-20 \pm 11$ & $6 \pm 23$ & NS & $-58 \pm 28$ & $14 \pm 270$ & NS \\
\hline 6.7 & $-10 \pm 11$ & $50 \pm 9$ & $<0.0005$ & $-45 \pm 143$ & $161 \pm 48$ & $<0.0025$ \\
\hline 16.7 & $23 \pm 19$ & $72 \pm 17$ & $<0.05$ & $544 \pm 198$ & $302 \pm 62$ & NS \\
\hline
\end{tabular}

potent in stimulating glucagon than insulin release. The clear stimulatory effect of VIP on insulin but not glucagon release during normoglycaemia in rats and hyperglycaemia in pigs argues against the suggestion [26] that insulin secretion induced by VIP is secondary to prior stimulation of glucagon release.

An important finding is that during normoglycaemia, VIP also stimulates somatostatin release. The interaction between glucose and substances releasing somatostatin is almost unknown. We have also demonstrated that, in contrast to VIP, a sulphonylurea drug (glibenclamide) markedly stimulates somatostatin release from the perfused rat pancreas in the presence of low glucose concentrations ( $3.3 \mathrm{mmol} / \mathrm{l}$ or less) whereas the effect was less pronounced at $4.4 \mathrm{mmol} / \mathrm{l}$ glucose [7].

The significance of glucose for the effects of VIP in the pancreas is further emphasized by studies of its effects on insulin and somatostatin release induced by increasing glucose concentrations. VIP was clearly synergistic with glucose over a broad range of concentrations of this hexose $(6.7$ to $33.3 \mathrm{mmol} / \mathrm{l})$. A remarkable finding was that the peptide exerted a more prominent effect on early than on late insulin and somatostatin release. This would imply that VIP sensitizes both $\mathrm{B}$ and $\mathrm{D}$ cells for the action of glucose. On the other hand, VIP seems to sensitize A but not B cells when arginine is used as stimulator.

These marked effects of VIP on the release of islet hormones are in contrast to in vivo studies. In rats, a dose as large as $2 \mu \mathrm{g} / \mathrm{kg}$ of VIP induced only a slight increase in serum insulin [29]. When VIP was given as a continuous IV infusion in rats at a dose of $40 \mathrm{ng} / \mathrm{kg} / \mathrm{min}$, there was no effect on basal or glucose or arginine induced, insulin or glucagon release (unpublished observations). The comparison between in vitro and in vivo effects of VIP suggests that, in rats, VIP plays a role in the regulation of the function of $\mathrm{A}, \mathrm{B}$, and $\mathrm{D}$ cells provided that the peptide released from VIP containing islet nerve terminals exerts a direct local action.
Since in the present experiments we used porcine VIP some caution is warrented when extending our results to a possible physiological significance of VIP in rat islets. Rat VIP is not available at present.

Acknowledgements. The study was supported by the Swedish Research Council (grant no. 19X-00034-16), Nordisk Insulin Foundation, and Swedish Diabetes Association. The authors thank Miss Britt-Marie Witasp for her expert secretarial assistance.

\section{References}

1. Bloom SR, Iversen J (1976) Gut hormones and the alpha cell. Metabolism 25 [Suppl 1]: 1457-1458

2. Buffa R, Capella C, Solcia E, Frigerio B, Said SI (1977) Vasoactive Intestinal Peptide (VIP) cells in the pancreas and gastro-intestinal mucosa. Histochemistry 50: 217-227

3. Creutzfeldt W (1979) The incretin concept today. Diabetologia 16: $75-85$

4. Efendić S, Nylén A, Roovete A, Uvnäs-Wallensten K (1978) Effects of glucose and arginine on the release of immunoreactive somatostatin from the isolated rat pancreas. FEBS Lett 22: 33-35

5. Efendić S, Hökfelt T, Luft R (1978) Sornatostatin. In: Levin $\mathrm{R}$, Luft $\mathrm{R}$ (eds) Advances in metabolic disorders, vol 9. Academic Press, New York San Francisco London, p 368-424

6. Efendic S, Lins PE, Luft R (1978) Somatostatin and insulin secretion. Metabolism 27 [Suppl 1]: 1275-1281

7. Efendić S, Enzmann F, Nylén A, Uvnäs-Wallensten K, Luft R (1979) Glucose and a sulfonylurea interaction in the release of insulin, glucagon and somatostatin from isolated perfused rat pancreas. Proc Natl Acad Sci USA 76: 5901-5904

8. Faloona GR, Unger RH (1974) Glucagon radioimmunoassay. In: Jaffe BM, Behrman HR (eds) Methods of hormone radioimmunoassay. Academic Press, New York, p 317-330

9. Grossman MJ (1974) Condidate hormones of the gut. Gastroenterology 67: 730-755

10. Hales CN, Randle PJ (1963) Immunoassay of insulin with insulin-antibody precipitate. Biochem J 88: 137-145

11. Ipp E, Dobbs RE, Unger RH (1978) Vasoactive intestinal peptide stimulates pancreatic somatostatin release. FEBS Lett 90 : 76-78

12. Kaneto AT, Kaneko T, Kajinuma H, Kosaka K (1977) Effect of vasoactive intestinal polypeptide infused intrapancreatically on glucagon and insulin secretion. Metabolism 26: 781-786

13. Larsson LI, Edvinsson L, Fahrenkrug J, Håkanson R, Owman C, Schaffalitzky de Muckadell OB, Sundler F (1976) 
Immunohistochemical localisation of a vasodilatory polypeptide (VIP) in cerebrovascular nerves. Brain Res 113: 400-404

14. Larsson LI, Fahrenkrug J, Schaffalitzky de Muckadell OB, Sundler F, Håkansson R, Rehfeld JF (1976) Localisation of vasoactive intestinal polypeptide (VIP) to central and peripheral neurons. Proc Natl Acad Sci USA 73: 3197-3200

15. Larsson LI, Fahrenkrug J, Holst JJ, Schaffalitzky de Muckadell OB (1978) Innervation of the pancreas by vasoactive intestinal polypeptide (VIP) immunoreactive nerves. Life Sci 22: 773-780

16. Lindkaer Jensen S, Fahrenkrug J, Holst JJ, Vagn Nielsen $O$, Schaffalitzky de Muckadell OB (1978) Secretory effects of VIP on isolated perfused porcine pancreas. Am J Physiol 235: E 387-E 391

17. Loubatières A, Mariani MM, Ribes G, de Malbose H, Chapel J (1969) Etude experimentale d'un nouveau solfamide hypoglycémiant particulièrement actif, le $\mathrm{Hb} 419$ on glibenclamide. Diabetologia 5: 1-10

18. Luft R, Efendić S, Hökfelt T (1978) Somatostatin - both hormone and neurotransmitter? Diabetologia 14: 1-13

19. Modin J, Bryant MG, Polak JH, Bloom SR, Albuquerque RH, Pearse AGE (1976) Possible dual role for VIP as gastrointestinal hormone and neurotransmitter substance. Lancet I: 991-993

20. Mutt V, Said SI (1974) Structure of the porcine vasoactive intestinal octacosapeptide. Eur J Biochem 42: 581-589

21. Orci L, Malaisse-Lagae F, Ravazzda M, Rouiller D, Renold AE, Perrelet A, Unger R (1975) A morphological basis for intracellular communication between alpha and beta cells in endocrine pancreas. J Clin Invest 56: 1066-1070

22. Said SI, Mutt V (1970) Polypeptide with broad biological activity: isolation from smal intestine. Science 169: 1217-1218

23. Schaffalitzky de Muckadell OB, Fahrenkrug J, Holst JJ (1977)
Release of vasoactive intestinal polypeptide (VIP) by electric stimulation of the vagal nerves. Gastroenterology 12: 373-375

24. Schaffalitzky de Muckadell OB, Fahrenkrug J, Holst JJ, Lauritsen KB (1977) Release of vasoactive intestinal polypeptide (VIP) by intraduodenal stimuli. Scand J Gastroenterol 12: 793-799

25. Schauder P, McIntosh C, Panten U, Arends J, Arnold R, Frerichs $\mathrm{H}$, Creutzfeldt W (1977) Dynamics of somatostatin release from isolated rat panceatic islets. FEBS Lett 81 : 355-358

26. Schebalin M, Said SI, Makhlouf GM (1977) Stimulation of insulin and glucagon secretion by vasoactive intestinal peptide. Am J Physiol 232: E 197-E 200

27. Sundler F, Alumets J, Håkanson R, Fahrenkrug J, Schaffalitzky de Muckadell OB (1978) Peptidergic (VIP) nerves in pancreas. Histochemistry 55: 173-176

28. Sundler F, Aluments J, Håkanson R, Ingemansson S, Fahrenkrug J, Schaffalitzky de Muckadell OB (1977) VIP innervation of the gallbladder. Gastroenterology 72: 1375-1377

29. Turner DS, Etheridge L, Marks V, Brown JC, Mutt V (1974) Effectiveness of the intestinal polypeptides, IRP, GIP, VIP and motilin on insulin release in the rat. Diabetologia 10: $459-463$

Received: August 20, 1979, and in revised form: February 29, 1980

Suad Efendić, M. D.

Department of Endocrinology

Karolinska Hospital

S-104 01 Stockholm

Sweden 